\title{
FAKTOR PENYEBAB INEFEKTIVITAS FUNGSI TERMINAL BANDAR RAYA PAYUNG SEKAKI (BRPS) KOTA PEKANBARU
}

\author{
Suryaningsih \\ Universitas Abdurrab Pekanbaru \\ Email : suryaningsih@gmail.com
}

\begin{abstract}
Pengelolaan sektor publik merupakan tanggung jawab pemerintah daerah sebagai pengelola fasilitas publik yang ada di daerah. Terminal sebagai salah satu fasilitas publik yang ada di daerah memiliki fungsi yang sangat vital bagi perkembangan sebuah kota. Terminal memiliki peran yang sangat penting, akan tetapi masih banyak terminal yang ada di daerah di seluruh Indonesia tidak berjalan secara efektif. Salah satu terminal yang tidak efektif tersebut adalah termnal Tipe A yang ada di Kota Pekanbaru. Tulisan ini membahas tentang faktor penyebab inefektivitas fungsi terminal Bandar Raya Payung Sekaki (BRPS) Kota Pekanbaru. Tujuan dari penelitian ini adalah untuk mendeskripsikan dan menganalisa faktor penyebab inefektivitas fungsi terminal Bandar Raya Payung Sekaki (BRPS) Kota Pekanbaru. Metode yang digunakan dalam penelitian ini adalah kualitatif deskriptif dengan menggunakan teknik wawancara, observasi, dan dokumentasi sebagai alat untuk pengumpulan data di lapangan. Hasil penelitian menunjukkan bahwa ada 3 faktor utama penyebab inefektivitas terminal Bandar Raya Payung Sekaki (BRPS) yakni, faktor kebijakan, faktor sosial lingkungan (tata ruang, keamanan, dan aksesibilitas), dan faktor kelembagaan.
\end{abstract}

Kata Kunci: Terminal, Implementasi Kebijakan, Bandar Raya Payung Sekaki (BRPS)

\section{Abstract}

Public sector management is the responsibility of local governments as managers of public facilities in the region. Terminal as one of the public facilities in the area has a function that is vital for the development of a city. Terminal has a very important role, but there are still many terminals that exist in regions throughout Indonesia are not running effectively. One such ineffective terminal is Type A terminals in Pekanbaru City. This paper discusses the factors causing inefectivity function of Bandar Raya Payung Sekaki terminal (BRPS) Pekanbaru City. The purpose of this study is to describe and analyze factors causing the inefectivity function of Bandar Raya Payung Sekaki terminal (BRPS) Pekanbaru City. The method used in this research is qualitative descriptive by using interview technique, observation, and documentation as a tool for data collection in the field. Result of research indicate that there are 3 main factors causing inefektivitas terminal of Bandar Raya Payung Sekaki (BRPS) that is, policy factor, environment social factor (spatial, security, and accessibility), and institutional factor.

Keywords: Terminal, Policy Implementation, Bandar Raya Payung Sekaki (BRPS)

\section{PENDAHULUAN}

Pemerintah daerah sebagai sebagai penyedia sarana publik/fasilitas publik harus menempatkan masyarakat sebagai muara dari pengelolaan sektor publik tersebut. Berbagai fasilitas publik/umum harus disediakan oleh pemerintah daerah untuk memenuhi kebutuhan masyarakatnya dalam berbagai bidang, salah satunya dalam bidang transportasi. Sebagai fasilitas pendukung kehidupan manusia, transportasi tidak dapat dipisahkan dari aspek-aspek aktivitas hidup manusia (Miro, 2004). Transportasi telah berkembang menjadi salah satu kebutuhan manusia yang paling mendasar. 
Transportasi merupakan sebuah proses, yakni proses pindah, proses gerak, proses mengangkut dan mengalihkan. Proses ini membutuhkan alat pendukung untuk menjamin lancarnya proses perpindahan sesuai dengan waktu yang diinginkan. Alat pendukung ini diistilahkan dengan sistem transportasi yang di dalamnya mencakup berbagai unsur, yakni ruang untuk bergerak (jalan), tempat awal/akhir pergerakan (terminal), yang bergerak (alat angkut/kendaraan dalam bentuk apapun), dan pengelolaan (yang mengkoordinasikan ketiga unsur sebelumnya). Masing-masing unsur tersebut tidak bisa hadir dan beroperasi sendiri-sendiri, kesemuanya harus terintegrasi secara serentak (Miro, 2004).

Jumlah barang yang diangkut setiap tahunnya akan terus meningkat. Hal ini disebabkan oleh adanya pertambahan jumlah penduduk, peningkatan arus urbanisasi, produksi barang-barang ekonomi, pertambahan pendapatan dan kesejahteraan, perkembangan wilayah, pertumbuhan pusat-pusat kegiatan, serta pertambahan keinginan untuk melakukan perjalanan. Peningkatan jumlah barang tersebut harus didukung dengan pengembangan sistem transportasi (jalan, kendaraan umum, dan terminal). Jika hal ini tidak diantisipasi maka akan menimbulkan dampak, yakni kemacetan, kesemrawutan lalu lintas, sulitnya suatu kawasan berkembang, dan tingginya biaya ekonomi yang terjadi.

Untuk mencegah atau menangani hal tersebut, pemerintah daerah melakukan serangkaian kebijakan terkait dengan pengembangan sistem transportasi. Perkembangan sebuah kota sangat tergantung dengan perencanaan dan pengembangan sistem transportasi tersebut, yakni dengan melakukan pembangunan jalan raya, penambahan kendaraan umum, dan juga melakukan pembangunan terminal. Terminal memegang peranan yang sangat penting untuk menciptakan keterpaduan, kelancaran, dan ketertiban roda transportasi sebuah kota.

Terminal dapat diartikan sebagai prasarana angkutan yang merupakan bagian dari sistem transportasi untuk melancarkan arus penumpang dan barang (Juknis LLAJ, 1995). Berdasarkan Keputusan Menteri Perhubungan Nomor 31 tahun 1995, terminal penumpang dibagi menjadi 3 jenis yaitu, pertama, Terminal Penumpang Tipe A yang melayani jasa angkutan Antar Kota Antar Propinsi (AKAP), Antar Kota Dalam Propinsi (AKDP), angkutan kota, dan angkutan pedesaan. Kedua, Terminal Penumpang Tipe B untuk angkutan Antar Kota Dalam Propinsi (AKDP), angkutan kota dan/atau angkutan pedesaan. Ketiga, Terminal Penumpang Tipe $\mathrm{C}$ yang berfungsi melayani kendaraan umum untuk angkutan pedesaan.

Pemerintah daerah di Indonesia banyak mengalami permasalahan dalam pengelolaan terminal, baik itu terminal tipe $\mathrm{A}, \mathrm{B}$, maupun $\mathrm{C}$. Banyak terminal yang ada di daerah tidak berfungsi sebagaimana mestinya, seperti Terminal Regional Bingkuang (TRB) Sumatera Barat (http://www.ganto.or.id), Terminal Giwangan di Yokyakarta (http://yogyakarta.bpk.go.id), Terminal Regional Daya di Kota makassar (http://rakyatsulsel.com), Terminal Terboyo di Semarang (http://jateng.tribunnews.com), dan Terminal Bandar Raya Payung Sekaki (BRPS) Kota Pekanbaru.

Di Kota Pekanbaru masih banyak ditemukan terminal bayangan dan loket kendaraan AKAP dan AKDP yang berada di luar terminal Bandar Raya Payung Sekaki BRPS (http://detakriau.com). Hal ini menunjukkan bahwa fungsi dari Terminal Bandar Raya Payung Sekaki (BRPS) belum berjalan secara efektif. Dalam Peraturan Walikota Nomor 238 tahun 2005 tentang Penyelenggaraan dan Pengelolaan Terminal Penumpang Kota Pekanbaru menetapkan bahwa terminal angkutan jalan Kota Pekanbaru, terdiri dari:

a.Terminal bus Bandar Raya Payung Sekaki sebagai Terminal Regional dan klasifikasi tipe A yang melayani bus AKAP, AKDP, angkutan kota, dan angkutan penumpang umum lainnya.

b.Terminal Mayang Terurai dengan klasifikasi B yang melayani angkutan kota dan angkutan penumpang lainnya.

c.Terminal Mekar Sari, Terminal Rumbai, dan Terminal Senapelan dengan klasifikasi tipe C yang melayani angkutan kota dan angkutan penumpang umum lainnya. 
Berdasarkan peraturan walikota tersebut, terlihat bahwa Terminal Bandar Raya Payung Sekaki (BRPS) merupakan terminal regional dengan klasifikasi tipe A. Dalam Peraturan Daerah Kota Pekanbaru No. 2 tahun 2009 tentang Lalu Lintas dan Angkutan Jalan di Kota Pekanbaru dan Keputusan Walikota No. 235 tahun 2005 tentang Penetapan Angkutan Jalan dalam Kota Pekanbaru dijelaskan bahwa terminal penumpang tipe A berfungsi melayani kendaraan umum untuk Angkutan Antar Kota Antar Provinsi (AKAP) atau Angkutan Lintas Batas Negara, Angkutan Antar Kota Dalam Provinsi (AKDP), angkutan kota, dan angkutan pedesaan. Selain itu, ditegaskan bahwa setiap kendaraan angkutan umum yang beroperasi dalam dan/melintas wilayah Kota Pekanbaru wajib memasuki terminal sesuai trayek yang telah ditetapkan.

Terminal Bandar Raya Payung Sekaki (BRPS) dibangun pada tahun 2002 dan mulai diefektifkan pada tahun 2005. Terminal ini dibangun diatas lahan seluas 27 ha. Terminal BRPS dibangun untuk menggantikan terminal Mayang Terurai yang sudah tidak mampu lagi menampung jumlah angkutan umum yang ada dan berakibat pada kemacetan. Terminal Bandar Raya Payung Sekaki (BRPS) Kota Pekanbaru adalah bangunan terminal termegah di Indonesia. Pembangunan terminal ini menghabiskan dana sekitar 57 miliar yang dilengkapi fasilitas lengkap (http://avlenrein.blogspot.com). Fasilitas lengkap tersebut adalah Jalur pemberangkatan dan kedatangan kendaraan umum, tempat tunggu kendaraan umum, tempat istirahat sementara kendaraan umum, bangunan kantor terminal, tempat tunggu penumpang atau pengantar, menara pengawas (traffic control), loket penjualan karcis, parkir kendaraan pegunjung, pelataran taxi, kamar kecil/toilet, mushola, kios/kantin, kafe, ruang pengobatan, ruang informasi, penitipan barang, taman, dan hotel/penginapan.

Pada tahun 2006 terjadi penurunan jumlah bus angkutan AKAP, AKDP, angkutan kota, ataupun angkutan pedesaan yang mangkal di terminal. Terminal yang sudah dirancang dan dibangun dengan lengkap dan megah ini belum berfungsi sebagaimana mestinya. Hal tersebut dapat dilihat dari masih banyaknya kegiatan menaikkan dan menurunkan penumpang di luar terminal. Saat ini banyak ruas-ruas jalan yang ada di Kota Pekanbaru menjadi terminal bayangan. Hal ini menunjukkan adanya permasalahan pada terminal Bandar Raya Payung Sekaki (BRPS) dalam menjalankan fungsinya. Inilah yang menjadikan penelitian menarik untuk dilakukan.

a. Faktor Kebijakan

Kebijakan menurut Thomas Dye (Subarsono, 2008) adalah apapun pilihan pemerintah untuk melakukan atau tidak melakukan (public policy is whatever governments choose to do or not to do). Konsep ini sangat luas karena mencakup sesuatu yang dilakukan atau tidak dilakukan oleh pemerintah. Definisi tersebut mengandung makna bahwa (1) kebijakan publik tersebut dibuat oleh badan pemerintah, bukan organisasi swasta; (2) kebijakan publik menyangkut pilihan yang harus dilakukan atau tidak dilakukan oleh badan pemerintah.

Kebijakan publik juga dapat didefinisikan sebagai serangkaian instruksi dari para pembuat keputusan kepada pelaksana kebijakan yang menjelaskan tujuan-tujuan dan cara-cara untuk mencapai tujuan tersebut. Pada dasarnya terdapat banyak batasan dan defenisi mengenai kebijakan publik. Perbedaan ini timbul karena masing-masing ahli mempunyai latar belakang yang berbeda-beda. Masingmasing definisi tersebut cukup memuaskan untuk menjelaskan satu aspek, namun besar kemungkinan gagal dalam menjelaskan aspek yang lain (Winarno, 2008). Dalam penelitian ini kebijakan publik dapat dipahami sebagai kebijakan yang dibuat oleh badan-badan pemerintah dan para aktor politik yang bertujuan untuk menyelesaikan masalah terkait dengan pengelolaan Terminal Bandar Raya Payung Sekaki (BRPS) Kota Pekanbaru.

\section{b. Faktor Sosial Lingkungan}

Salah satu faktor kunci dalam mengevaluasi efektivitas sebuah terminal menurut Iseki et al (2007) dalam (Noor, Nasrudin, dan Foo, 2014) adalah faktor keamanan. Dijelaskan bahwa terminal harus 
memberikan rasa aman pada penumpang baik pada siang hari maupun pada malam hari. Selain itu, Fahrezi (2014) dalam penelitiannya yang berjudul "Padang Kota Tanpa Terminal" menjelaskan bahwa masalah keamanan penumpang merupakan faktor yang menyebabkan rendahnya tingkat pemanfaatan Terminal Regional Bingkuang (TRB) Kota Padang.

c. Faktor Kelembagaan

Carr (1986) dalam (Noor, Nasrudin, dan Foo, 2014) menyatakan ada enam indikator dalam mengukur efektivitas transportasi umum, salah satunya adalah umpan balik dari berbagai pemangku kepentingan seperti pelanggan, masyarakat, bus, lembaga transportasi, dan sopir bus. Dalam hal ini jika dikaitkan dengan efektif atau tidaknya sebuah terminal dapat juga dilihat dari kerjasama antara pelanggan, masyarakat, bus, lembaga transportasi, dan sopir bus.

\section{HASIL DAN PEMBAHASAN}

a. Sekilas Tentang Kota Pekanbaru

Kota Pekanbaru merupakan ibukota dari Provinsi Riau yang terletak antara 1010 14' - 1010 34' Bujur Timur dan 00 25' - 00 45' Lintang Utara. Kota ini berada pada ketinggian 5-50 meter diatas permukaan laut, yang memiliki batas-batas sebagai berikut:

a. Sebelah Utara: Kabupaten Siak dan Kabupaten Kampar

b. Sebelah Selatan: Kabupaten Kampar dan Kabupaten Pelalawan

c. Sebelah Timur: Kabupaten Siak dan Kabupaten Pelalawan

d. Sebelah Barat: Kabupaten Kampar

Kota Pekanbaru memiliki luas wilayah 632,26 Km2. Berdasarkan Peraturan Daerah Kota Pekanbaru No. 4 Tahun 2003, kota ini memiliki 12 Kecamatan 58 kelurahan/desa. Kota Pekanbaru sebagai ibukota Provinsi Riau telah berkembang menjadi pusat perdagangan, pendidikan, industri, pelayanan jasa, dan pemerintahan. Perkembang tersebut tentu didukung dengan tersedianya sarana dan prasarana perhubungan darat, sungai, dan udara.

\section{b. Terminal Bandar Raya Payung Sekaki (BRPS)}

Terminal Bandar Raya Payung Sekaki (BRPS) merupakan terminal terbesar di Kota Pekanbaru dan termegah di Indonesia. Pembangunan terminal ini menghabiskan dana sebesar 57 miliar dengan fasilitas lengkap. Terminal BRPS dibangun pada tahun 2002 dan mulai di efektifkan pada tahun 2005. Terminal Bandar Raya Payung Sekaki (BRPS) Kota Pekanbaru terletak di Kelurahan Air Hitam Kecamatan Payung Sekaki Kota Pekanbaru. Luas kawasan terminal adalah 27 Ha dengan luas bangunan pendukung 7 Ha. Pengelolaan dan pengoperasian Terminal Bandar Raya Payung Sekaki (BRPS) dilakukan oleh Unit Pelaksana Teknis Dinas (UPTD) terminal berdasarkan Surat Keputusan (SK) Walikota Pekanbaru dengan Nomor KPTS.821.4/BKD/2009/028. UPTD ini berfungsi merencanakan, melaksanakan, mengevaluasi, dan melaporkan setiap program dan rencana kerja yang berhubungan dalam upaya memaksimalkan fungsi terminal di Kota Pekanbaru.

c. Faktor-Faktor yang Mempengaruhi Inefektivitas Terminal Bandar Raya Payung Sekaki (BRPS) Kota Pekanbaru

Menurut Peraturan Daerah (Perda) No. 2 Tahun 2009 Tentang lalu Lintas dan Angkutan Jalan di Kota Pekanbaru pasal 1 (ayat 50) disebutkan bahwa terminal adalah prasarana transportasi jalan untuk keperluan memuat dan menurunkan orang dan/atau barang serta mengatur kedatangan dan keberangkatan kendaraan umum, yang merupakan salah satu wujud simpul jaringan transportasi. Berdasarkan pasal tersebut dapat dipahami bahwa terminal memiliki fungsi pertama, tempat untuk memuat dan menurunkan orang dan barang, kedua, tempat mengatur kedatangan dan keberangkatan kendaraan umum. Berdasarkan 
perda tersebut, terminal Bandar Raya Payung Sekaki (BRPS) tidak menjalankan kedua fungsi itu karena bus/mobil melakukan kegiatan menurunkan atau menaikkan penumpang di luar terminal. Bus/mobil yang memiliki izin trayek melintasi terminal hanya untuk membayar retribusi. Hal ini tentu saja melanggar pasal 48 ayat (s) Perda No. 2 Tahun 2009 bahwasannya setiap bus/mobil yang memiliki izin trayek diwajibkan menaikkan dan menurunkan penumpang pada tempat yang telah ditentukan.

Ada 3 (tiga) faktor utama yang menyebabkan tidak efektifnya Terminal Bandar Raya Payung Sekaki (BRPS) Kota Pekanbaru, yakni:

1. Faktor Kebijakan

Terminal Bandar Raya Payung Sekaki (BRPS) Kota Pekanbaru dibangun untuk menggantikan Terminal Mayang Terurai yang terletak di Jalan Nangka/Tuanku Tambusai. Ada beberapa alasan pembangunan terminal BRPS ini, yakni pertama, Terminal Mayang Terurai terletak di pusat kota yang berakibat pada kemacetan. Hal ini kemudian diperparah lagi dengan pertumbuhan penduduk di Kota Pekanbaru yang semakin padat oleh pendatang. Kedua, Terminal Mayang Terurai terlalu kecil dan sempit sehingga tidak lagi mampu menampung jumlah penumpang yang hilir mudik disana. Terminal Bandar Raya Payung Sekaki (BRPS) diresmikan pada tahun 2005, namun setahun kemudian terminal ini sudah mulai sepi dari penumpang. Terminal BRPS tidak layak disebut sebagai "terminal" karena seharusnya terminal ini ramai dengan penumpang yang ingin pergi atau datang dari Kota Pekanbaru, akan tetapi terminal ini jauh dari aktivitas tersebut. Kegiatan menaikkan dan menurunkan penumpang terjadi di pinggir jalan yang menuju keluar Kota Pekanbaru, seperti di Jalan Hr. Soebrantas yang menuju Sumatera Barat. Terminal Bandar Raya Payung Sekaki (BRPS) merupakan terminal penumpang tipe A yang berfungsi melayani kendaraan umum untuk angkutan antar kota antar propinsi dan/atau angkutan lintas batas negara, angkutan antar kota dalam propinsi, angkutan kota, dan angkutan pedesaan.

Salah satu penyebab terjadinya terminal bayangan di Kota Pekanbaru adalah tidak efektifnya fungsi terminal. Terminal tidak efektif karena tidak adanya evaluasi kebijakan setelah dibangunnya terminal Bandar Raya Payung Sekaki (BRPS) oleh pemerintah Kota Pekanbaru. Evaluasi perlu dilakukan karena tidak semua program kebijakan yang dibuat oleh pemerintah meraih hasil yang diinginkan (Winarno, 2008). Pemerintah Kota Pekanbaru melalui Dinas Perhubungan, Komunikasi, dan Informatika perlu melakukan pengkajian yang lebih mendalam terkait tidak efektifnya terminal yang dibangun dengan anggaran yang cukup besar ini. Pemerintah Kota Pekanbaru tidak memiliki rencana pengembangan daerah di sekitar terminal yang dapat menarik masyarakat untuk beraktivitas di sekitar terminal.

Dinas Perhubungan, Komunikasi, dan Informatika Kota Pekanbaru harus lebih tegas dalam menertibkan terminal-terminal bayangan yang ada. Razia terhadap terminal bayang telah dilakukan berkali-kali oleh dinas perhubungan, Komunikasi, dan Informatika, namun hal ini tidak menyelesaikan akar permasalahan sebenarnya. Hingga saat ini terminal Bandar Raya Payung Sekaki (BRPS) masih sepi dari penumpang dan agen-agen perusahaan pemilik angkutan masih banyak berada di luar terminal.

2. Faktor Sosial Lingkungan

a. Faktor Tata Ruang

Penentuan lokasi Terminal Bandar Raya Payung Sekaki (BRPS) dilakukan dengan memperhatikan rencana kebutuhan lokasi simpul jaringan transportasi jalan yang merupakan bagian dari rencana umum tata ruang kota (RUTK). Hal ini tidak sinkron dengan perkembangan kondisi riil kota dengan konsep yang diterapkan. Pembangunan terminal tidak sesuai dengan pola pergerakan masyarakat. Lokasi terminal kurang mempertimbangkan karakter kota sebagai tujuan. Terminal berdiri sendiri tanpa ada bangunan lain. Bangunan yang dimaksud disini adalah seperti hotel, Rumah Toko (RUKO), rumah makan, perumahan, pusat perbelanjaan dan bangunan pendukung lainnya. Saat ini lokasi di sekitar terminal hanya lahan kosong atau kebun sawit, jikapun ada itu hanya rumah penduduk non permanen dan bangunan liar yang banyak dikomersialkan seperti warung yang menjual minuman keras yang ramai 
dikunjungi oleh pemabuk dan pencari hiburan kelas bawah. Selain itu, disekitar terminal juga terdapat warung remang-remang tempat karaoke dan jika telah diatas jam 19.00 WIB beberapa ruas jalan di sekitar lokasi terminal hanya terdapat beberapa penjual jagung dengan pelanggan muda mudi yang lagi kasmaran sehingga menjadi tempat mesum dan ajang balapan geng motor.

\section{b. Faktor Keamanan}

Salah satu faktor permasalahan yang dihadapi oleh Terminal Bandar Raya Payung Sekaki (BRPS) adalah faktor keamanan penumpang. Seyogyanya terminal beroperasi selama 24 jam, akan tetapi Terminal Bandar Raya Payung Sekaki (BRPS) buka pada pukul 07.00 WIB dan tutup pada pukul 19.00 WIB. Mobil bus yang kedatangannya lewat dari pukul 19.00 WIB tidak mau menurunkan penumpang di Terminal Bandar Raya Payung Sekaki (BRPS) karena sunyinya terminal pada waktu tersebut. Sunyinya Terminal Bandar Raya Payung Sekaki (BRPS) sangat rawan dengan kejahatan bagi para penumpang seperti yang disampaikan oleh salah seorang sopir bus LORENA dan salah satu penumpangnya. Para penumpang lebih memilih tidur di Pool LORENA daripada harus turun dan tidur di Terminal Bandar Raya Payung Sekaki (BRPS) yang sunyi hingga pagi tiba. Selain itu, pada siang hari kondisi Terminal Bandar Raya Payung Sekaki (BRPS) juga tidak memberikan kenyamanan kepada penumpang. Begitu banyak calo, copet, dan preman yang ada disana. Dalam kondisi sepi penumpang bisa saja diikuti oleh pencopet. Hal ini di dukung pula dengan telah rusaknya berbagai fasilitas pendukung terminal, seperti toilet, mushalla, dan lain-lain.

c. Faktor Aksesibilitas

Rendahnya aksesibilitas ke lokasi terminal merupakan salah satu penyebab tidak berfungsinya Terminal Bandar Raya Payung Sekaki (BRPS) Kota Pekanbaru. Rendahnya aksesibilitas tersebut dapat dilihat dari beberapa indikasi ini, yakni: pertama, waktu perjalanan menjadi lebih lama jika memanfaatkan terminal, hal ini disebabkan oleh terbatasnya angkutan umum yang menuju Terminal Bandar Raya Payung Sekaki (BRPS). Salah satu angkutan umum yang melintas di terminal adalah Bus Trans Metro Pekanbaru (TMP). TMP memiliki trayek tersendiri dan hal ini memakan waktu yang lama untuk menuju terminal. Kedua, biaya atau ongkos menuju terminal menjadi lebih mahal, karena angkutan yang dapat diandalkan untuk bisa langsung menuju ke Terminal Bandar Raya Payung Sekaki (BRPS) adalah taxi. Ketiga, tidak terletak pada titik kritis pergantian moda angkutan, seperti persimpangan jalan arteri tempat pertemuan angkutan regional dengan angkutan kota. Keempat, tidak terletak pada daerah seperti pemukiman, kawasan industri, dan pusat-pusat kegiatan kota. Kelima, tidak integral dengan sistem angkutan primer lainnya seperti pelabuhan laut, bandara, dan lain-lain.

\section{Faktor Kelembagaan}

Faktor lain yang menyebabkan inefektifitas Terminal Bandar Raya Payung Sekaki (BRPS) Kota Pekanbaru adalah faktor kelembagaan. Berdasarkan SK Walikota Pekanbaru bahwasannya pengelolaan dan penyelenggaraan Terminal Bandar Raya Payung Sekaki (BRPS) dilakukan oleh Unit Pelaksana Teknis Dinas (UPTD) terminal. Kegiatan penyelenggaraan terminal meliputi kegiatan pengelolaan, pemeliharaan, dan penertiban terminal. Untuk kegiatan pengelolaan terminal meliputi kegiatan perencanaan, pelaksanaan, dan pengawasan operasional terminal. Unit Pelaksana Teknis Dinas (UPTD) terminal dalam pengelolaan dan penyelenggaraan Terminal Bandar Raya Payung Sekaki, terdiri dari Kepala UPTD terminal, Kepala Sub Bagian Tata Usaha (Kasubag TU), dan dibantu oleh beberapa orang staff. Staff tersebut ada yang mengurusi administrasi dan pendapatan terminal, urusan pengendalian dan pengoperasian terminal, serta urusan ketentraman dan ketertiban terminal yang keseluruhannya berjumlah 80 orang (Dinas Perhubungan, Komunikasi dan informatika Kota Pekanbaru, 2015).

Banyaknya jumlah staff yang ada di Unit Pelaksana Teknis Dinas (UPTD) terminal, tidak berbanding lurus dengan tugas yang harus mereka lakukan. Ada beberapa tugas Unit Pelaksana Teknis 
Dinas (UPTD) terminal, yakni pertama, penyusunan rencana kerja, kedua, pelaksanaan evaluasi tugas, ketiga, pengaturan keberangkatan dan kedatangan, keempat, penertiban operasional terminal, kelima, pelaksanaan program $\mathrm{K} 3$, keenam, pemungutan retribusi dan sewa, ketujuh, penyetoran retribusi dan sewa, delapan, pembuatan laporan, sembilan, pengkoordinasian dengan instansi dan lembaga terkait, dan sepuluh, pelaksanaan tugas lain sesuai dengan fungsinya. Dari sepuluh tugas tersebut kegiatan pemungutan retribusi saja yang berlangsung aktif di terminal. Pungutan ini diwajibkan bagi travel yang telah terdaftar untuk membayar retribusi.

Terkait dengan terminal bayangan yang marak di Kota Pekanbaru, Unit Pelaksana Teknis Dinas (UPTD) terminal tidak melakukan kerjasama dengan instansi dan lembaga terkait, misalnya dengan Satuan Polisi Pamong Praja (Satpol PP) dan pihak kepolisian. Selain itu, kerjasama juga tidak tidak dilakukan dengan agen-agen, supir bus, penumpang, dan masyarakat. Melihat tidak efektifnya Terminal Bandar Raya Payung Sekaki (BRPS), DPRD Kota Pekanbaru juga tidak berbuat apa-apa. Tidak ada langkah nyata dalam mengefektifkan terminal ini.

\section{KESIMPULAN}

Dari uraian yang telah penulis jabarkan diatas dapat disimpulkan bahwa Pemerintaha Kota Pekanbaru belum memiliki kebijakan yang tegas terkait dengan pengefektifan Terminal Bandar Raya Payung Sekaki (BRPS) dengan menertibkan terminal bayangan yang semakin marak. Faktor-faktor sosial lingkungan seperti faktor tata ruang, faktor keamanan, dan faktor aksesibilitas juga mempengaruhi inefektivitas Terminal Bandar Raya Payung Sekaki (BRPS). Selain itu, faktor kelembagaan juga mempengaruhi tidak efektifnya terminal karena kelembagaan inilah yang mengatur dan mengelola terminal. Jadi, berfungsi atau tidaknya terminal tergantung dari pengelolaan lembaga yang telah diamanahi tanggungjawab.

\section{SARAN}

Ada beberapa saran demi efektifnya Terminal Bandar Raya Payung Sekaki (BRPS) Kota Pekanbaru, pertama, Pemerintah Kota Pekanbaru melalui Dinas Perhubungan, Komunikasi dan Informatika harus mengambil kebijakan yang tegas terkait dengan terminal bayangan yang ada di Kota Pekanbaru dengan melakukan kerjasama dengan instansi terkait dan stakeholder. Kedua, penertiban terminal bayangan tentu tidak akan sukses tanpa adanya dukungan atau pembenahan di terminal itu sendiri, yakni terkait dengan faktor tata ruang, keamanan dan aksesibilitas yang harus segera ditangani oleh Pemerintah Kota Pekanbaru.

\section{DAFTAR PUSTAKA}

[1]. Edward, Morlok, K. 1991. Pengantar Teknik dan Perencanaan Transportasi. Jakarta: Erlangga.

[2]. Felson, Marcus, et al. 1996. Redesigning Hell: Preventing Crime and Disorder at the Port Authority Bus Terminal. National Criminal Justice Reference Service Publication, 1-88.

[3]. Gallion, Arthur B dan Eisner, Simon. 1996. Pengantar Perancangan Kota: Desain dan Perencanaan Kota. Jakarta: Erlangga. 
[4]. Izmail, Rozmi, et al. 2012. Passengers Preference and Satisfaction of Public Transport in Malaysia. Australian Journal of Basic and Applied Sciences, 6(8): 410-416.

[5]. Miro, Fidel. 2004. Perencanaan Transportasi. Jakarta:Erlangga.

[6]. Moleong, Lexy J. 2004. Metode penelitian Kualitatif, Bandung: PT. Remaja Rosdakarya.

[7]. Peraturan Daerah Kota Pekanbaru No. 2 tahun 2009 tentang Lalu Lintas dan Angkutan Jalan di Kota Pekanbaru.

[8]. Peraturan Walikota No. 8 tahun 2009 tentang Susunan Organisasi, Tugas, dan Fungsi Unit Pelaksana Teknis Dinas (UPTD) Pada Dinas Perhubungan, Komunikasi, dan Informatika Kota Pekanbaru.

[9]. Keputusan Walikota No. 235 tahun 2005 tentang Penetapan Angkutan Jalan Dalam Kota Pekanbaru.

[10].Peraturan Walikota No. 238 tahun 2005 tentang Penyelenggaraan Dan Pengelolaan Terminal Penumpang Kota Pekanbaru.

[11].Putra, Fadillah. Paradigma Kritis Dalam Studi Kebijakan Publik. Surabaya: Pustaka Pelajar, 2003.

[12]. Saputra, T. (2016). Pengaruh Motivasi Kerja Terhadap Disiplin Kerja Pegawai Pada Dinas Pemuda Dan Olahraga Provinsi Riau. Jurnal Niara, 8(2), 50-60.

[13]. Sinulingga, Budi D. 2005. Pembangunan Kota: Tinjauan Regional dan Lokal. Jakarta: Pustaka Sinar harapan.

[14].Subarsono, AG. 2008. Analisis Kebijakan Publik (Konsep, Teori, dan Aplikasi). Yogyakarta: Pustaka Pelajar.

[15].Sugiyono. 2005. Memahami Penelitian Kualitatif. Bandung: CV. Alfabeta.

[16].Winarno, Budi. Kebijakan Publik: Teori dan Proses. Yogyakarta: MedPress, 2008. 